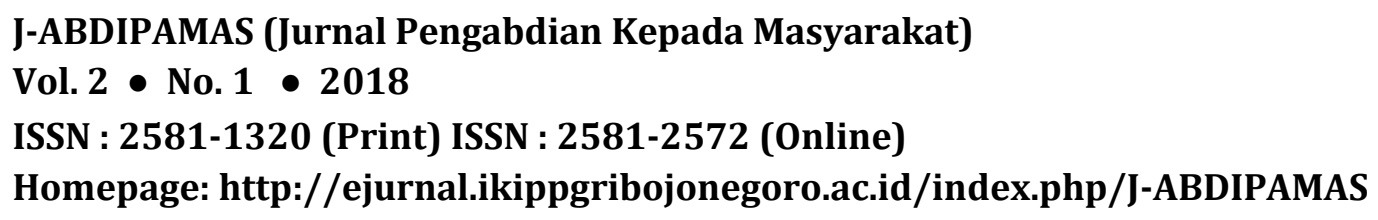

\title{
ANALISIS BUTIR SOAL PILIHAN GANDA DENGAN APLIKASI KLASIKA
}

\author{
Destiniar $^{1}$, Dina Octaria² ${ }^{\text {, Anggria Septiani Mulbasari }}{ }^{3}$ \\ 1Universitas PGRI Palembang. Email: destiniarpgri@yahoo.co.id \\ 2Universitas PGRI Palembang. Email: dinaoktaria@gmail.com \\ 3Universitas PGRI Palembang. Email: tia.pasca@yahoo.co.id
}

\begin{abstract}
This current Community Service Activities (PkM) is based on the lack of ability and willingness of teachers to analyze multiple choice items. The objectives of PkM are to (1) improve teachers 'ability to perform student data processing using classical applications, (2) increase teachers' willingness and ability in analyzing multiple choice items, (3) to assist teacher to analyze item analysis with classical program, (4) improve the ability of teachers to analyze the items so as to obtain a good question. The current PkM activity was held by short training for twice meeting with 20 teachers in SMA Negeri 1 Jejawi. The researcher used lectute, discussion, question and answer, simulation, and demonstration method for this PkM activity. The result showed that there was an increas of teacher's will and ability in processing and analyze multiple choice items using clasical applications.
\end{abstract}

Keywords: analysis, clasical application, item

\begin{abstract}
ABSTRAK
Kegiatan Pengabdian kepada Masyarakat PkM ini dilatarbelakangi dari kurangnya kemampuan dan kemauan guru untuk menganalisa butir soal pilihan ganda. Tujuan PkM adalah untuk (1) meningkatkan kemampuan guru dalam melakukan pengolahan data jawaban siswa menggunakan aplikasi klasika, (2) meningkatkan kemauan dan kemampuan guru dalam menganalisa butir soal pilihan ganda (3) membantu guru untuk melakukan analisis butir soal dengan program klasikal, (4) meningkatkan kemampuan guru menganalisis butir soal sehingga diperoleh soal yang baik. Kegiatan PkM ini dilaksanakan dalam bentuk pelatihan singkat selama dua kali pertemuan dengan banyaknya peserta berjumlah 20 orang guru di SMA Negeri 1 Jejawi. Metode yang digunakan dalam melaksanakan kegiatan PkM ini adalah dengan metode ceramah, diskusi, tanya jawab, simulasi dan demonstrasi. Hasil yang diperoleh selama kegiatan PkM yaitu adanya peningkatan kemauan dan kemampuan guru dalam melakukan pengolahan data dan menganalisa butir soal pilihan ganda menggunakan aplikasi klasika.
\end{abstract}

Kata Kunci : analisis, aplikasi Klasika, butir soal

\section{PENDAHULUAN}

Keberhasilan suatu proses pendidikan dapat diketahui salah satunya dengan melakukan evaluasi atau penilaian. Penilaian (assessment) pendidikan adalah proses yang tidak terpisahkan dari pendidikan itu sendiri. Menurut Musial et.al (dalam Sumintono, 2015) Tujuan penilaian pendidikan meliputi lima hal sebagai berikut : 1) 
memberikan umpan balik (feedback), 2) menentukan apa yang dipelajari selanjutnya, 3) diagnosis kesulitan belajar dan miskonsepsi, 4) menentukan kemajuan belajar dan mengetahui perkembangannya, 5) sebagai alat evaluasi dan akuntabilitas program.

Salah satu bentuk penilaian pendidikan yaitu melalui tes (ujian). Suatu bentuk ujian yang bisa menginformasikan prestasi antarsiswa atau antar sekolah bahkan antar daerah memerlukan tes standar yang baik. Untuk menghasilkan tes yang berkualitas diperlukan guru yang memiliki kemampuan dalam menulis soal dan memiliki kemauan untuk mengembangkan kemampuan dirinya dalam pembuatan soal. Menurut Mardapi (dalam Purnomo, 2007) untuk membuat soal yang baik seorang guru harus memiliki kemampuan khusus yaitu : (1) menguasai materi pelajaran yang diujikan, (2) mampu membahasakan gagasan, (3) memahami karakteristik individu yang diuji, dan (4) menguasai teknik penulisan soal. Soal yang telah dibuat tidak begitu saja dianggap sudah baik, perlu dilakukan pengujian soal. Menurut Suyabrata (dalam Purnomo, 2007) langkah yang harus dilakukan dalam pengujian soal secara empiris meliputi : ujicoba, analisis soal, seleksi soal dan kompilasi soal ke dalam bentuk akhir.

Soal tes terdiri dari soal dalam bentuk uraian dan soal pilihan ganda. Menurut Supranata (2005) soal pilihan ganda adalah soal yang jawabannya harus dipilih dari beberapa kemungkinan jawaban yang telah disediakan. Menurut Slameto (dalam Arif, 2014) Soal pilihan ganda memiliki beberapa kelebihan yaitu (1) mengukur berbagai jenjang kognitif (dari ingatan sampai dengan evaluasi), (2) penkorannya mudah, cepat, obyektif, dan dapat mencakup ruang lingkup bahan/materi yang luas dalam suatu tes untuk suatu kelas atau jenjang pendidikan, (3) bentuk ini sangat tepat untuk ujian yang pesertanya sangat banyak atau hasilnya harus segera diumumkan, seperti ujian semester, ujian sekolah, dan ujian akhir semester. Sedangkan keterbatasan dari soal pilihan ganda yaitu : (1) memerlukan waktu yang relatif lama untuk menulis soalnya, (2) sulit membuat pengecoh yang homogen dan berfungsi, (3) terdapat peluang untuk menebak kunci jawaban.

Pada umumnya guru berkeyakinan bahwa soal yang telah disusunnya baik sehingga guru berharap hasil yang dicapai siswa juga baik, namun jika kenyataan nya tidak sesuai dengan harapannya guru harus menelaah kualitas hasil tes nya untuk mengevaluasi suatu perangkat tes yang telah dibuat. Pada kenyataan di lapangan, guru jarang sekali mengadakan evaluasi terhadap perangkat tes yang telah dibuat, hal ini dikarenakan untuk membuat soal dan menganalisisnya membutuhkan waktu yang lama.

Kegiatan menganalisis butir soal merupakan suatu kegiatan yang harus dilakukan guru untuk meningkatkan mutu soal yang telah ditulis. Kegiatan tersebut meliputi pengumpulan, peringkasan, penelaahan, dan penggunaan informasi dari jawaban siswa untuk membuat keputusan tentang setiap penilaian. Tujuan penelaahan adalah untuk mengkaji dan menelaah setiap butir soal agar diperoleh soal yang bermutu sebelum soal digunakan. Di samping itu, tujuan analisis butir soal juga untuk membantu meningkatkan tes melalui revisi atau membuang soal yang tidak efektif, serta untuk mengetahui informasi diagnostik pada siswa apakah mereka sudah/belum memahami materi yang telah diajarkan, serta untuk melihat sebaran kemampuan siswa, tingkat kesulitan butir soal, tingkat kesesuaian butir soal, dan tingkat kesesuaian individu yang 
akan menunjukkan indikasi terjadinya saling contek, siswa tidak cermat, dan adanya tebakan dalam menjawab soal.

Berdasarkan uraian di atas, kegiatan pengabdian kepada masyarakat ini bertujuan untuk (1) meningkatkan kemampuan guru dalam melakukan pengolahan data jawaban siswa menggunakan aplikasi klasika, (2) meningkatkan kemauan dan kemampuan guru dalam menganalisa butir soal pilihan ganda, (3) membantu guru untuk melakukan analisis butir soal dengan program klasikal, (4) meningkatkan kemampuan guru menganalisis butir soal sehingga diperoleh soal yang baik.

\section{METODE PELAKSANAAN}

Kegiatan pengabdian kepada masyarakat ini dilaksanakan di SMA Negeri 1 Jejawi, dengan alamat Jalan Raya Desa Lingkis Kecamatan Jejawi Kabupaten Ogan Komering Ilir 30652. Kegiatan pengabdian ini dilaksanakan 2x tatap muka yaitu

Tabel 1. Waktu Pelaksanaan

\begin{tabular}{|c|c|c|c|c|}
\hline No & $\begin{array}{l}\text { Hari, } \\
\text { tanggal }\end{array}$ & Pukul & Tim PkM & Kegiatan \\
\hline 1 & $\begin{array}{l}\text { Senin, } 22 \\
\text { Jan } 2018\end{array}$ & $\begin{array}{l}08.00- \\
12.00\end{array}$ & $\begin{array}{l}\text { Destiniar } \\
\text { Dina Octaria } \\
\text { Anggria Septiani MS }\end{array}$ & $\begin{array}{l}\text { Penjelasan dari tim PkM tentang pentingnya } \\
\text { analisis soal, cara analisis soal dengan } \\
\text { menggunakan aplikasi klasika. }\end{array}$ \\
\hline 2 & $\begin{array}{l}\text { Senin, } 29 \\
\text { Jan } 2018\end{array}$ & $\begin{array}{l}08.00- \\
12.00\end{array}$ & $\begin{array}{l}\text { Destiniar } \\
\text { Dina Octaria } \\
\text { Anggria Septiani MS }\end{array}$ & $\begin{array}{l}\text { Praktek cara menganalisis soal dibimbing oleh } \\
\text { tim PkM dengan menggunakan aplikasi klasika. }\end{array}$ \\
\hline
\end{tabular}

Peserta kegiatan Pengabdian kepada Masyarakat ini adalah guru-guru di SMA Negeri 1 Jejawi yang berjumlah 20 orang dengan menggunakan metode ceramah, diskusi, tanya jawab, simulasi dan demonstrasi dalam masing-masing kelompoknya dengan bimbingan tim Pengabdian.

\section{Realisasi Kegiatan}

Para peserta dibagi ke dalam 5 kelompok dengan masing-masing kelompok terdiri dari 4 peserta.

\section{a. Pertemuan pertama}

Pada pertemuan pertama, sebelumnya tim PkM menjelesaskan perlunya atau pentingnya analisis butir soal, mengenalkan program klasika dan menginstal program klasikal. Lalu tim PkM membahas tentang penyiapan berkas data mentah dalam bentuk microsoft excel (data mentah yang harus disiapkan yaitu jawaban siswa, kunci jawaban, dan kode data penyimpanan) sebelum menganalisis menggunakan aplikasi klasika, mengubah bentuk penyimpanan data dari microsoft excel dalam bentuk *.prn sebelum menganalisis menggunakan aplikasi klasika, dan menjelaskan langkah-langkah untuk menganalisis soal dengan menggunakan aplikasi klasika yang akan dipraktekan pada pertemuan kedua. 


\section{b. Pertemuan kedua}

Pada pertemuan kedua, tim PkM menjelaskan bagaimana cara mengelolah data menggunakan aplikasi klasika, serta tim memberikan arahan dan bimbingan kepada guru dalam mempraktekkan aplikasi klasika. Yang akan dibahas yaitu tentang cara menganalisis soal khususnya soal pilihan ganda dengan aplikasi klasika, analisis yang dilakukan terhadap sebaran kemampuan siswa, tingkat kesulitan butir soal, tingkat kesesuaian butir soal, dan tingkat kesesuaian individu yang akan menunjukkan indikasi terjadinya saling contek, siswa tidak cermat, dan adanya tebakan dalam menjawab soal, dan tim pengabdian memberikan kesempatan kepada setiap kelompok untuk menganalisa butir soal yang sudah mereka buat dan dipraktekkan.

\section{HASIL DAN PEMBAHASAN}

Kegiatan kepada masyarakat ini dilaksanakan selama dua kali pertemuan, yaitu pertemuan pertama pada tanggal 22 Januari 2018 dan pertemuan kedua pada tanggal 29 Januari 2018. Berdasarkan pengamatan selama kegiatan pengabdian kepada masyarakat berlangsung, diperoleh hasil yang positif, yakni:

a. Para peserta menunjukkan perhatian yang sangat tinggi terhadap materi pengabdian (menyimpan jawaban mahasiswa, mengubah bentuk data dari Ms. Excel ke dalam bentuk *prn, Praktek menggunakan Aplikasi Klasika, dan menganalisis jawaban siswa).

b. Para peserta aktif bertanya jika mereka menemukan kesulitan selama mengikuti praktek.

c. Para peserta menunjukkan antusiasme dalam mengikuti tahap-tahap kegiatan.Antusiasme peserta terlihat karena banyaknya pertanyaan yang muncul dari peserta yang artinya mereka benar-benar menyimak apa yang disampaikan oleh tim pengabdian. Di samping itu, antusiasme membuat mereka mampu memahami dan melaksanakan kerja kelompok dengan baik di akhir sesi kegiatan ini dan terlihat mereka sangat termotivasi untuk berlatih menggunakan aplikasi klasika serta menganalisis jawaban siswa. Berikut adalah gambar kegiatan yang dilakukan oleh tim pengabdian kepada masyarakat.

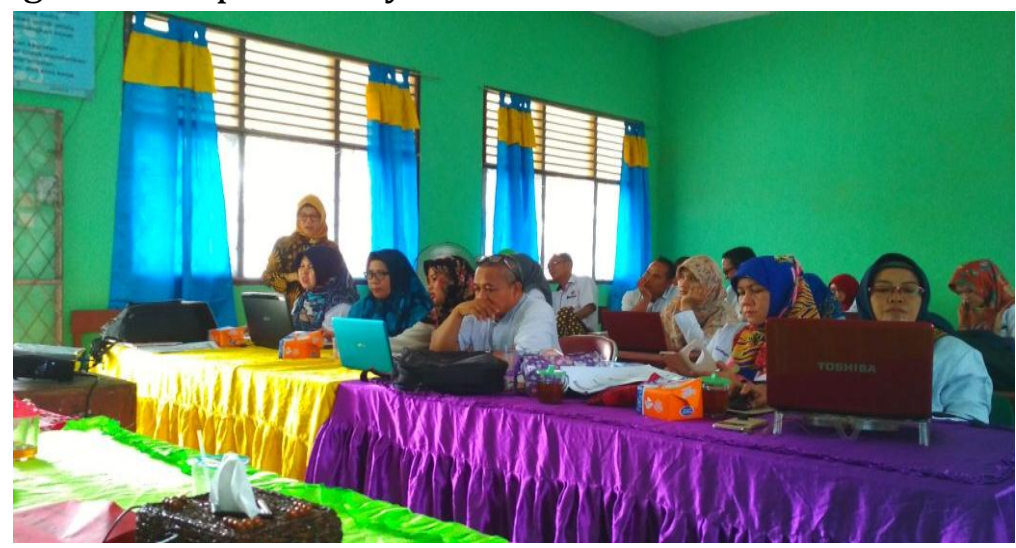

Gambar 1. Peserta sedang berlatih menggunakan Aplikasi Klasika 
Berdasarkan uraian di atas, yaitu hasil yang didapatkan peserta dengan menggunakan aplikasi klasika, bahwa menganalisis data itu sangat penting, menurut Anastasi and Urbina (1997), maanfaat dari menganalisis data itu yaitu : (1) dapat membantu para pengguna tes dalam evaluasi atas tes yang digunakan, (2) sangat relevan bagi penyusunan tes informal dan lokal seperti tes yang disiapkan guru untuk siswa dikelas, (3) mendukung penulisan butir soal yang efektif, (4) secara materi dapat memperbaiki tes dikelas, (5) meningkatkan validitas soal dan reliabilitas, dari penjelasan para ahli tersebut bahwa dengan menganalisis data atau soal, hasil analisis yang diperoleh adalah soal yang baik, dengan instrumen yang baik akan diperoleh hasil pengukuran yang tepat dan yang baik, salah satunya dengan aplikasi klasika digunakan.

Menurut Millman, dkk (1993), aplikasi klasika adalah proses penelaahan butir soal melalui informasi dari jawaban peserta didik untuk meningkatkan mutu butir soal yang bersangkutan dengan menggunakan teori tes klasika. Kelebihan analisis butir soal secara klasika adalah murah, dapat dilaksanakan sehari-hari dengan cepat menggunakan komputer, murah, sederhana, familier dan dapat menggunakan data dari beberapa peserta didik atau sampel kecil, maka dari itu aplikasi klasika dapat membantu guru dalam menganalisis soal.

\section{PENUTUP}

Berdasarkan hasil pelaksanaan kegiatan, diperoleh kesimpulan bahwa kegiatan PkM ini dapat: (1) meningkatkan kemampuan guru dalam melakukan pengolahan data jawaban siswa menggunakan aplikasi klasika, (2) meningkatkan kemauan dan kemampuan guru dalam menganalisa butir soal pilihan ganda, (3) membantu guru untuk melakukan analisis butir soal dengan program klasikal, (4) meningkatkan kemampuan guru menganalisis butir soal sehingga diperoleh soal yang baik.

Pelaksanaan pelatihan, partisipasi, dan motivasi peserta sudah berjalan dengan baik. Namun demikian, berdasarkan hasil pelaksanaan yang telah dilaksanakan maka disarankan beberapa hal sebagai berikut.

a. Biaya untuk pelaksanaan kegiatan hendaknya lebih ditingkatkan, sehingga dapat melaksanakan kegiatan lebih variatif dan lebih lama.

b. Berdasarkan permintaan peserta, hendaknya kegiatan-kegiatan pelatihan seperti yang telah dilaksanakan dapat ditingkatkan frekuensi pelaksanaannya.

\section{UCAPAN TERIMA KASIH}

Tim PkM mengucapkan terima kasih pada (1) Universitas PGRI Palembang yang telah memberikan bantuan dana DIVA UPGRI Palembang, dan (2) LPPkMK Universitas PGRI Palembang yang telah memfasilitasi kegiatan PkM.

\section{DAFTAR PUSTAKA}

Anastasi. Anne and Urbina, Suasana. (1997). Psicoholological Testing. (Seventh Edition). New Jersey:Prentice-Hall,Inc. 
Millman, Jason and Greene, Jennifer. (1993).The Spesification and Development of Tests of Achiievement and Ability in Robert L. Lin (Editor). Educational Measurement, Third Edition. Phoenix: American Council on Education, Series on Higher Education Oryx Press.

Purnomo, A. (2007). Kemampuan Guru dalam Merancang Tes Berbentuk Pilihan Ganda pada Mata Pelajaran IPS untuk Ujian Akhir Sekolah (UAS). Lembaran Ilmu Kependidikan, Jilid 36, No. 1, Juni 2007.

Sumintono, B \& Widhiarso, B. (2015). Aplikasi Pemodelan Rasch pada Assessment Pendidikan. Cimahi: Trim Komunikata.

Supranata. (2005). Panduan Penulisan Tes Tertulis.Bandung: Remaja Rosdakarya. 